\title{
NOBODY KNOWS: OPPRESSION AND RESISTANCE IN THE NARRATIVES OF FREDERICK DOUGLASS AND OLAUDAH EQUIANO
}

Gladir da Silva Cabral $^{1}$

\begin{abstract}
This article intends to analyze the autobiographic narratives by Frederick Douglass and Olaudah Equiano, two important slave narratives. Equiano was born free in Africa, was captured and fled from slavery to live in London; and Douglass was born in slavery, from African descendants. Equiano lived in the 18th century and Douglass in the 19th century. After a brief presentation and contextualization of the genre slave narrative, the works selected are analyzed, having as focus their critical content in relation to religion, economy, the legal system, and language. The analysis allows us to understand how such cultural and social elements usually employed to oppress the slaves were used as instrument of confrontation of slavery and search for autonomy. Some of my theoretical references are: Henry Louis Gates Jr., Alex Argyros, Roger Rosenblatt, Edward Said, and Jacques Derrida.
\end{abstract}

Keywords: Frederick Douglass; Olaudah Equiano; Slave Narratives; Narratives of Freedom.

\section{“NOBODY KNOWS": OPRESSÃO E RESISTÊNCIA NAS NARRATIVAS DE FREDERICK DOUGLASS AND OLAUDAH EQUIANO}

Resumo: Este trabalho propõe-se a analisar as narrativas autobiográficas de Frederick Douglass e Olaudah Equiano, dois relatos de escravos, um deles nascido na África (Equiano) e outro descendente de africanos e nascido nos Estados Unidos (Douglass). Equiano viveu durante o século XVIII e Douglass viveu durante o século XIX. Logo após uma breve apresentação e contextualização do gênero narrativa de escravos, analisam-se as obras selecionadas, tendo como foco seu conteúdo crítico em relação à religião, economia, sistema jurídico e linguagem. A análise permitiu perceber que tais elementos culturais e sociais utilizados geralmente para oprimir o escravo serviram como instrumentos de crítica e enfrentamento na busca por autonomia. Como referenciais teóricos, destacam-se Henry Louis Gates Jr., Alex Argyros, Roger Rosenblatt, Edward Said e Jacques Derrida.

Palavras-chave: Frederick Douglass; Olaudah Equiano; Narrativas de Escravos; Narrativas de Liberdade.

1 Doutorado em Letras (Inglês e Literatura Correspondente) pela Universidade Federal de Santa Catarina (2000) e professor da Universidade do Extremo Sul Catarinense, no curso de Letras e no Programa de Pós-Graduação em Educação. E-mail: gla@unesc.net 
“Oh, nobody knows the troubles I've seen / Nobody knows but Jesus". These are the first lines of a Negro Spiritual, a religious song composed by slaves denouncing the oppression of the time and the hopes of freedom. They testify about the cultural-historical crisis of the African American people, their problems of social segregation and limitation. Negro Spirituals function as important narratives and poems which help the enslaved people to organize reality and have some kind of historical comprehension. They sing, they narrate, at least to God and to themselves, about the sufferings of slavery, the hypocrisy of that oppressive society, and the desire for a different kind of social order.

The narratives of Frederick Douglass and Olaudah Equiano operate an important function in the foundation of an African American cultural identity. They narrate their stories sometimes using the words and categories of the oppressor and sometimes recreating the terms and reshaping language (APPIAH, 1988), performing an ambiguous movement of critique of social oppression and assimilation and resistance to the Western culture. They survive socially and historically, by narrating their stories in a language that both translates the words and values of white people and undermines those values and words in a very subtle way.

Kwame Anthony Appiah, commenting about the African American cultural identity in a Pan African context, quotes Frantz Fanon when he says that " $[\mathrm{t}]$ he Negro is never so much a Negro as since he has been dominated by whites" (APPIAH, 1988, p. 164). Appiah associates the African American identity with historical oppression, understanding that the whites "invented the Negroes in order to dominate them" (p. 164). In that sense, negritude is a European creation for ideological purposes. Similarly, Jacques Derrida understands the apartheid regime in South Africa as an European creation, a "European discourse", that is, "a discourse [which] belongs to a whole system of phantasms, to a certain representation of nature, life, history, religion, and law, to the very culture which succeeded in a giving rise to this state takeover" (DERRIDA, 1985, p. 294).

When Jacques Derrida writes about apartheid in South Africa, he makes some important relations between racism and discourse, saying that "[s] urely, an idiom should never incline toward racism. It often does, however, and this is not altogether fortuitous: there's no racism without a language" (DERRIDA, 1985, p. 292). Racism, slavery, and black people oppression are based on authorizing discourse. Black narratives start a dialogue with this racist discourse, being conscious of oppression, resisting, and counteracting.

Taking into consideration the ideological devices behind social institutions and cultural values, one can read Olaudah Equiano's and Frederick Douglass' narratives as a critique of slavery as a Western culture (Euro-American) institution, a critique of social oppression, a critique of the false religious practices. This critique is presented through the assimilation and resistance of the Western culture, its religious and moral values, in a dialectical movement of acceptance and resistance, of conservation and recreation. The objective of this article is to analyze the autobiographic narratives by Frederick Douglass and Olaudah Equiano, having as focus their critical content in relation to religion, economy, the legal system, and language. Equiano was born free in Africa, he was captured and fled from slavery to live in London; and Douglass was born in slavery, from African descendants. Equiano lived in the 18th century and Douglass in the 19th century.

First, it is necessary to define some terms such as institution, culture, and society, in order to give precision and specificity to the analysis. By institution, it is understood the fixed, limited set 
of ideas, organizations, values, functions which validate, determine, and operate social relations in terms of hierarchy and power relations. Literary history, for example, makes possible the maintenance of texts as an institution (canon) and, together with the official constitution of a national history, it makes possible the creation and maintenance of a nation (APPIAH, 1988). By culture this paper understands the total amount of elements which constitute society. In a way, society determines culture, creating and recreating its values, and in another way, culture determines society, influencing and controlling social relations. Edward Said defines culture as "an environment, process, and hegemony in which individuals in their private circumstances and their works are embedded" (SAID, 1983, p. 8). Said, emphasizing the relation between the environment and the individuals, stresses that culture is both something to which the individuals belong and something that one possesses. Quoting Lionel Trilling, Said comments that culture is also "a system of discriminations and evaluations" (p. 11), something that points out to ideological elements, forces, and aspects. By society I understand, in harmony with Said, the "material base over which culture tries, through the great men of culture, to extend its sway" (p. 10). Society is the visible ideology, in which the State, the political organization based on the idea of nation, is the supreme incarnation of the power of culture. The written text also is the visible manifestation of a social relation, because "for every poem or novel in the canon there is a social fact being requisitioned for the page, a human life engaged, a class suppressed or elevated" (p. 23).

Critical thinking is the only instrument by which it becomes possible for the individuals to find out and create their own identities, and to resist "tyranny, domination, and abuse" (SAID, 1983, p. 29), and exercise the right of human freedom and dignity. Critical thinking becomes possible when the individual distinguishes the historical and political elements which give foundation to society. Critical thinking is also possible when there is a sense of history, a past-present-future (GATES JR., 1983). Douglass and Equiano were limited by the circumstances and ideas of their time, but to a certain extent they achieve some critical thinking, creating for themselves an identity, dominating language, questioning power relations and social institutions, and helping their people to resist oppression.

From the literary point of view, it is necessary to understand that slave narratives have already been developed as an independent genre. Charles T. Davis and Henry Louis Gates Jr. call them "imaginative reconstruction of human bondage narrated by hundreds of former chattel slaves" and consider them "veritable repositories of the ontological and epistemological concerns of human beings enslaved in antebellum America" (1991, p. v). Paul Lovejoy prefers to call them "narratives of freedom", because they focus of the search and fight for freedom (LOVEJOY, 2011). Olaudah Equiano is known as one of the first black man to narrate his own experience from slavery to freedom, and Frederick Douglass developed this genre and created one of the most important black narratives in history. Black narratives have some patterns, for "the stories have been similar to each other as well" and "black fiction has continued to function within patterns peculiarly its own" (ROSENBLAT'T, 1974, p. 2). Forms and symbols of Black Narratives, continues Rosenblatt, "have existed all along before" (p. 6). For example, in those narratives, the hero always learns something, "surviving a number of crisis", and relating his experience in a meaningful way, communicating and interpreting it (p. 178). Black narrative themes are also known for: wilderness versus frontier, the effects of forceful religion, exploration of psychological terror, personal versus national 
freedom, among other themes. Rosenblatt also adds that black narratives deal with the problem of white rejection, with defeat, with the impossibility of a self-reliant life, with humiliation and shame (p. 9). Another important component of black narratives is the conflict between individuals and mass oppression, which in a way has something to do with our contemporary dilemma: man and culture. Black narratives, says Rosenblatt, and this element can also be seen in Douglass' and Equiano's narratives, are full of ambiguities, because they can be "both American and anti- or extra-American, modern and anti-modern" (p. 11). Therefore, narratives can be used as instruments of oppression, in which "the social construction of reality is effected by the diffuse web of hegemonic power-relations constitutive of a given regime of power/truth" (ARGYROS, 1992, p. 660), or as instrument of resistance to oppression.

Slavery as a cruel cultural and economic invention is the main target of attack of Douglass' and Equiano's narratives critique. They resist against that oppressive institution, which survives even nowadays in the form modern slavery, xenophobia, economic segregation, and laws impeding or restricting immigration. They show critical thinking when they question the institutional authority and the authority of their own culture. They do not give up facing their own reality, but they resist and protest, and criticize. Douglass and Equiano were, in a way, their own creations, characters involved in a political, economic system and at the same time "trying to beat it", trying to change it (ROSENBLATT, 1974, p. 163). Slave narratives originated with two main interests: the exposure of the contradictions and atrocities of the regime of slavery and the questioning of the political and theological discourses which gave support to the system (SANTOS, 2011). They are marked by several forms of resistance (physical, psychological, linguistic, political...), by the pursuit of freedom and social equity, and by the effort for access to literacy and education (LEVINE, 2007; SEKORA, 1987).

Frederick Augustus Washington Bailey was born in Maryland 1818 and died in Washington in 1895. He was born in slavery, the son of a slave mother and a white father. Frederick Douglass never knew his father. He lived with his grandmother on a plantation. Later, working as servant in a house in Baltimore, he learned to read and write. In 1838, at the age of 21 , he escaped from slavery and started his journey to freedom and engaged in the antislavery movement. He became a writer and a great speaker against slavery. After the Civil War, he became consultant to President Abraham Lincoln and worked as minister and consul general to Haiti (1889-1891) (MERRIAM-WEBSTER， 1995). The book Narrative of the Life of Frederick Douglass: an American Slave was first published in 1845. Slave narratives were the first literary genre in prose produced by black writers in the United States.

In his book, Frederick Douglass criticizes slavery as an institution which dehumanizes and creates oppression. He treats slavery as a "whole system of fraud and inhumanity" (DOUGLASS, 2009, p. 80), recognizing the institutional character and the complexity of the problem. He describes several examples of how slavery deprives human beings of dignity, how it degenerates man and creates cruelty. "I never saw my mother," he says, "to know her as such, more than four or five times in my life; and each of those times was very short in duration, and at night" (p. 16). An example of the cruelty of the masters and how badly they treated the slaves can be seen in the passage of the old Barney, a slave appointed to take care of the horses of Colonel Lloyd: "I have seen Colonel Lloyd make old Barney, a man between fifty and sixty years of age, uncover his bald head, kneel down upon the cold, damp ground, and receive upon his naked 
and toil-worn shoulders more than thirty lashes at the time" (p. 30).

Describing the influence of slavery on the character of her mistress Sophia Auld, Douglass comments that although "[h]er face was made of heavenly smiles, and her voice of tranquil music", the "fatal poison of irresponsible power was already in her hands" (DOUGLASS, 2009, p. 44). Douglass is aware that slavery is a problem of power relations. "In entering upon the duties of a slaveholder, she did not seem to perceive that I sustained to her the relation of a mere chattel, and that for her to treat me as a human being was not only wrong, but dangerously so. Slavery proved as injurious to her as it did to me" (p. 48). Douglass argues that slavery influences and determines the individual's behavior and personality. The entire book is full of examples of cruelties committed under the shadows of slavery: lashes, rapes, murders, violence, injuries, offenses, terror, prohibitions, ignorance...

Olaudah Equiano was born in Essaka, Benin, which now belongs to Nigeria, in 1750, and belongs to the Igbo people. He was enslaved when he was 12 years of age and taken to the West Indies. After escaping slavery, he went to England and became an abolitionist, denouncing the slave system and the cruelty of slaver owners in Jamaica, which then belonged to the British Empire. He published his autobiography The Interesting Narrative of the Life of Olaudah Equiano, or Gustavus Vassa, the African in 1789. The book is full or his memories from Africa and the suffering of the African people in the hands of their masters. He died in England in 1797 (MERRIAM WEBSTER'S, 1995).

Olaudah Equiano also describes the horror of slavery, his rapture from the tribe, the separation from his family, from his country, from his cultural world, the sufferings in the slave ship where "the shrieks of the women, and the groans of the dying, rendered the vision a scene of horror almost inconceivable" (EQUIANO, 2018, p. 33). Equiano was also aware that the institutionalized oppression, the slave trade, “debauch men's minds and harden them to every feeling of humanity" (p. 79).

Religion is one of the elements that give support to slavery and works as an instrument of oppression. Both Douglass and Equiano denounce Christian faith as sanctification of atrocities, an ideology used to accommodate and dominate individuals in society. Equiano criticizes those who call themselves Christian and use religion as an excuse for oppression and domination. He says: "O, ye nominal Christians! Might not an African ask you, learned you this from your God, who says unto you, Do unto all men as you would ben should do unto you? Is it not enough that we are torn from our country and friends, to toil for your luxury and want of gain?” (EQUIANO, 2018, p. 37). However, Equiano balances his critique with some praises to a certain Captain Doran, a Quaker, "a very charitable and humane" master possessing "a most amiable disposition and temper" (EQUIANO, 2018, p. 69). Frederick Douglass, by his turn, is much more aggressive toward religion "in the South", "the Christianity of this land" (DOUGLASS, 2009, p. 115). In the Appendix, he criticizes this religion, which has "man-stealers for ministers, womenwhippers for missionaries, and cradle-plunderers for church members" (p. 116). He continues:

\begin{abstract}
[t]he man who wields the blood-clotted cowskin during the week fills the pulpit on Sunday, and claims to be a minister of the meek and lowly Jesus. The man who robs me of my earnings at the end of each week meets me as a class-leader on Sunday morning, to show me the way of life, and the path of salvation. He who sells my sister, for purposes of prostitution, stands forth as the pious advocate of purity. He who proclaims it a religious duty to read the Bible denies me the right of learning to read the name of the God who made me. (DOUGLASS, 2009, p. 116)
\end{abstract}

And he continues as he writes of "pollution", scattering of whole families, theft, adultery, and 
of "men sold to build churches, women sold to support the gospel, and babes sold to purchase Bibles for the poor heathen! All for the glory of God and the good of souls!" (p. 116). He is quite vehement in the final part of the book, when he writes that "[r] evivals of religion and revivals in the slave-trade go hand in hand together. The slave prison and the church stand near each other" (p. 116).

Another important extract in which Douglass denounces Christianity as an excuse for hiding power is when he describes his master Captain Auld, who "attended a Methodist camp-meeting". Douglass was disappointed because religion "neither made him to be humane to his slaves, nor to emancipate them. If it had any effect on his character, it made him more cruel and hateful in all his ways" (DOUGLASS, 2009, p. 62). Douglass shows acute awareness of the ideological function of religion when he says: "Prior to his conversion, [Captain Auld] relied upon his own depravity to shield and sustain him in his savage barbarity; but after his conversion, he found religious sanction and support for his slaveholding cruelty" (p. 63). Besides, among many other examples of cruelty "sanctioned" by religion, Douglass comments, in chapter $\mathrm{X}$, after the narration of the fight with $\mathrm{Mr}$. Covey, that

\begin{abstract}
the religion of the south is a mere covering for the most horrid crimes, - a justifier of the most appalling barbarity, - a sanctifier of the most hateful frauds, - and a dark shelter under, which the darkest, foulest, grossest and most infernal deeds of slaveholders find the strongest protection. Were I to be again reduced to the chains of slavery, next to that enslavement, I should regard being the slave of a religious master the greatest calamity that could befall me. For of all slaveholders with whom I have ever met, religious slaveholders are the worst. (p. 82)
\end{abstract}

And then he gives a long list of examples of cruelties practiced by members and ministers of the Reformed Methodist Church.
Analyzing the religious base for racism in South Africa, Derrida identifies a "theologicalpolitical discourse", which gives justification for the apartheid. Although being located in a different context (South Africa), Derrida's discussion on apartheid regime is pertinent to our analysis of religion, culture and power. Quoting some words from the Fundamental Principles of Calvinist Political Science, he observes that

[the Law of Segregation] is also founded in a theology and these Acts in Scripture. Since political power originates in God, it remains unified, indivisible. To accord individual rights "to immature social communities" and to those who "openly rebel against God, that is, the communists" would be a "revolt against God." (DERRIDA, 1992, p. 296)

In keeping with Derrida's argument, this particular Calvinist reading of the Scripture condemns democracy, "that universalism which seeks the root of humanity in a set of worldwide sovereign relations that include humanity in the whole". This interpretation suggests that "Scriptures and history each demonstrate that God requires Christian States" (p. 296). According to the proposals of the National Christian Education of 1948, Derrida comments, apartheid is the will of God (p. 296-7). However, Derrida recognizes the ambiguity of Christian theology, in the sense that the apartheid is both "upheld, to be sure, but also condemned in the name of Christ" (p. 297). Eugene Genovese also recognizes this ambiguity of Christian faith, which can be used as justification for cruelty as for goodness and dignity (GENOVESE, 1988).

Besides religion, economy based on human slavery is another element of attack for the black writers. Equiano describes the slaves being "conducted immediately to the merchant's yard, where [they] were all pent up together [...] without regard to sex or age" (EQUIANO, 2018, p. 35). Slaves become pure merchandise product. Equiano 
denounces this commerce and cries: "Must every tender feeling be likewise sacrifices to [white men] avarice?" (p. 36). And he adds that "it [was] common practice in the West Indies for men to purchase slaves though they have not plantations themselves" (p. 71). In his turn, Frederick Douglass, more emphatically, denounces his Mistress treating him as mere "chattel", not as a human being (DOUGLASS, 2009). In Chapter VIII, describing the valuation of Captain Anthony's properties, Douglass says that "[he] was immediately sent for, to be valued with the other property" (p. 54), and he comments that his feelings "rose up in detestation of slavery". "We were all ranked together at the valuation", says Douglass, “[m]en and women, old and young, married and single, were ranked with horses, sheep, and swine” (p. 55). Black writers denounce the slave trade, the economic exploitation. Slavery is not seen as something isolated only in terms of pure racism, but in terms of economic interest, economic structure, international affair of capturing, imprisoning, selling, and buying slaves.

Derrida, commenting on economic interest in the case of the South African regime of apartheid, says that racism and commerce go together and that Europe is also accomplice of that transaction, because " $t$ the survival of Western Europe depends on it" (DERRIDA, 1985, p. 295). Apartheid, as a posterior remnant of slavery black market, testifies that racism and oppression have economic motives and reasons. Economic exploitation gives motive for the institution of slavery and for every kind of economic oppression. Modern slavery is a European creation in order to achieve economic progress.

Along with slavery, religion, and economy, institutional justice becomes another target of attack for Douglass's and Equiano's narratives. Douglass spends an entire chapter denouncing injustice based on legal authority. He comments on
Chapter IV that "[n]o matter how innocent a slave might be - it availed him nothing, when accused by Mr. Gore of any misdemeanor. To be accused was to be convicted, and to be convicted was to be punished; the one always following the other with immutable certainty" (DOUGLASS, 2009, p. 34). In addition, he states that slaves "of course could neither institute a suit, nor testify against [a slaveholder]; and thus the guilty perpetrator of one of the bloodiest and most foul murderers goes unwhipped of justice, and uncensored by the community in which he lives" (p. 36). Douglass's wife's cousin murder case is striking. She was murdered, a young girl between fifteen and sixteen years of age, with a stick of wood. Everybody knew at that time the criminal was Mr. Giles Hick's wife, but she was not accused, nor judged, neither condemned.

Equiano narrates the cruel incident with "a free young mulatto-man who sailed a long time with [him]" and "he had a free woman for his wife, by whom he had a child" (EQUIANO, 2018, p. 86). Everybody "knew this young man from a child that he was always free, and no one had ever claimed as their property". But then a Bermudian captain came and arrested the poor mulatto, in spite of possessing a "certificate of his being born free in St Kitt's", a legal document (p. 86). There is no justice for the black people. Equiano also tells the story of a poor slave:

$[\ldots]$ after he had done working for his master,
he used to employ his few leisure moments to
go a fishing. When he had any fish, his master
would frequently take them from him without
paying him; and at other times some other
white people would serve him in the same
manner. [...] I can't go anybody to be righted
(p. 77), said the old man. There is one law for blacks and one law for whites. The sense of legal justice is so unfair that, according to the 329th Act, page 125, of the Assembly of Barbados, 
[...] if any negro, or other slave, under punishment by his master, or his order, for running away, or any other crime or misdemeanor towards his said master, unfortunately shall suffer in life or member, no person whatsoever shall be liable to a fine; but if any man shall out of wantonness, or only of bloody-mindedness, or cruel intention, wilfully kill a negro, or other slave, of his own, he shall pay into the public treasury fifteen pounds sterling (p. 77).

In relation to this critique of institutional justice, Derrida comments that the "repressive legal apparatus," the "juridical activity," is at the service of oppression, racism, apartheid (DERRIDA, 1985, p. 296). Then oppression acquires an authoritative legal discourse. Everything is possible. In Douglass' words, the "killing of a slave, or any colored person [...] is not treated as a crime" (DOUGLASS, 2009, p. 36).

Besides slavery, religion, economy, and law, language is used as another instrument of oppression. Derrida calls attention to the fact that "there's no racism without a language" (DERRIDA, 1985, p. 292) and that the apartheid, specifically, is "a European discourse" (p. 294). Argyros argues in the same direction when he says that narratives can be used as an instrument of oppression "ARGUROS, 1992, p. 660). There is this oppressive narrative, this oppressive discourse, this language used as an instrument of domination. Slaves had to learn in order to survive in that hostile environment, some of them had to learn English, French, and Deutsch. In order to avoid black people handling of language, they were forbidden to learn the written code. Frederick Douglass describes in detail the effort he made to learn how to read and write. Master Auld advises Sophia how language can be used as an instrument of oppression in a society in which to teach slaves to read "[was] almost an unpardonable offence" (DOUGLASS, 2009, p. 49). Reproaching his wife for teaching Douglass to read, Master Auld says: "If you give a nigger an inch, he will take an ell. A nigger should know nothing but to obey his master - to do as he is told to do. Learning would spoil the best nigger in the world" (p. 44).

Black narratives have a dialectical character, because on the one hand they overtly criticize slavery, religion, judicial system, and other elements of Western culture, but on the other hand they assimilate culture in order to survive in the hostile society, to resist oppressive use of institutional power, and in order to narrate their own stories. Analyzing black narratives as a genre, Rosenblatt says that "black heroes, despite strong efforts of resistance, gradually become mirrors themselves, and do not exist without the life outside them" (ROSENBLATT, 1974, p. 164). It is impossible to escape from cultural influence (the only way is dying). Clearly, Rosenblatt is talking about black narratives as a developed literary genre, but we can apply it to Douglass and Equiano, since they are the creators of the genre and the prototype of the black hero.

Through cultural assimilation both Douglass and Equiano can resist oppression and attain personal freedom, using the same weapons of the Western culture. They can survive socially by adapting culturally, mixing their African cultural tradition with their Euro-American cultural exile. By doing that, they change the Euro-American tradition and recreate it into a different cultural perspective. "Writing for and about [themselves], then, helps constitute the modern community of the nation; but [they] do it, largely, in languages imposed by the night of the legions" (APPIAH, 1988 , p. 156). But it is only because they use values and institutions of the Western society that they can create a larger movement and achieve larger and deeper effects. Of course, Equiano has an African background that Douglass does not have - Douglass is African American. They have had different experiences. If they had used only African language, values, symbols, they would not have an 
audience and could not succeed in the battle for freedom. Analyzing African musicians' use of English, Appiah gets to the conclusion that

[as] they developed new forms of music, drawing on instrumental repertoires and musical ideas with a dazzling eclecticism, Africa's musicians have also done astonishing things with a language used to be English. But it is as English that that language is accessible to millions around the continent" (APPIAH, 1988, p. 161),

And around the world. I think that the same can be said of Douglass' and Equiano's narratives reaching a European audience. This strategy of assimilating and using Western cultural elements in order to counter-act and recreate narrative and culture can be observed in both Douglass and Equiano. In their narratives it is possible to find the individual using institutions in order to resist these same social institutions and reconstruct their own cultural identity (APPIAH, 1988). As Gibson confirms, consciousness is the end of alienation and slavery (GIBSON, 1985), and in fact Douglass's fight for freedom starts with his critical consciousness - "This spirit made me a freeman in fact, though I still remained a slave in form" (DOUGLASS, 2009, p. 78). And Gibson adds: "A person is a slave, then, not when his body is held captive but when his psyche is not his own, when his self does not belong to him, when he does not exert resistance against those who would define him" (GIBSON, 1985, p. 556).

Religion is one of the fundamental elements of the Western culture which Douglass and Equiano assimilate in order to survive and resist cultural oppression. They select in the Christian religion some important aspects, motives, narratives, symbols and values which they could invoke and redefine. Genovese calls attention to the fact that the Christian faith, in spite of being used by the whites as an instrument of oppression, provided the black people with a set of narratives to identify with - like the story of the people of Israel being set free from Egypt -, and a sense of dignity, value, hope, and respect. He says:

Racism undermined in slaves their sense of value as black people and reinforced the dependency they felt in relation to white masters. Nevertheless, we are talking of tendencies, not absolute laws, and the slaves have forged defense weapons. The most important of them was religion, which taught them to love and value one another, to take a critical view in relation to their masters and to reject their ideological justifications for slavery itself. (GENOVESE, 1988, p. 24). ${ }^{2}$

And he continues: "Finally, searching for a religion, which was supposed to make them submissive and docile, slaves have rejected the essence of slavery and discovered their own rights and their value as human beings" (p. 25). ${ }^{3}$ They mixed their African spirituality with the Christian tradition and re-read the Bible, relating Jesus with Moses, and Israel with black nations, dreaming with freedom. Again quoting Genovese, I can say that "the religion of the slaves in the old South [...] presents the creative impulse of mixing ideas from several origins to formulate a world view complex enough and capable of reconciling the acceptance of what should be endured with a firm resistance to the pressures of despair and dehumanization" (p. 283-4). ${ }^{4}$ Not only religion, of course, but one could add that the whole humanist tradition, which gives value to written language, to memory, and democracy, also helps in this process 2 O racismo minava nos escravos o senso de valor como negros e reforçava a dependência que sentiam em relação aos senhores brancos. Não obstante, estamos falando de tendências, não de leis absolutas, e os escravos forjaram armas de defesa. A mais importante delas foi a religião, que lhes ensinava a se amarem e valorizarem uns aos outros, a assumirem uma visão crítica em relação aos senhores e a rejeitarem suas justificativas ideológicas para sua própria escravidão. (GENOVESE, 1988, p. 24).

3 "Por fim os escravos, recorrendo a uma religião que se supunha garantir-lhes a submissão e a docilidade, rejeitaram a essência da escravidão ao descobrir seus próprios direitos e seu valor como seres humanos" (p. 25).

4 "[a] religião dos escravos do Velho Sul [...] apresenta o impulse criativo de amalgamar ideias de diversas origens para formular uma visão de mundo suficientemente complexa e capaz de conciliar a aceitação do que tinha de ser suportado com uma firme resistência às pressões do desespero e da desumanização" (p. 283-4). 
of consciousness. Derrida also confirms that there are some elements in the Christian faith which invite resistance of oppression (DERRIDA). And he adds that, in order to criticize and change an oppressive and unjust society, "it is necessary to appeal unconditionally to the future of another law and another force lying beyond the totality of this present" (p. 298), and this is just what the Christian religion in his black version could offer.

Douglass refers to the Negro Spirituals, in Chapter II, as a religious manifestation of resistance, "prayer and compliant of souls boiling over with the bitterest anguish. Every tone was a testimony against slavery, and a prayer to God for deliverance from chains" (DOUGLASS, 2009, p. 26). Gates Jr. also compares those songs as a mixing of myth and reality, an interpretation of their slavery in terms of Biblical imagery (GATES JR., 1983, p. 97). He also says that the Spirituals were "the first black American poetry, at once impassionate and symbolic, the poetry of an ancient race passing through the throes of an enforced re-birth into the epoch of an alien and dominating civilization" (GATES JR., 1983, p. 103). Those songs reproduce the re-interpretation of the Christian tradition as an exercise of recreation of the cultural identity and resistance to an oppressive situation.

Another important citation of religion as an instrument of assimilation and resistance in Douglass' narrative is presented when he understands himself as being an "elect", a "chosen" by God's Providence to live in Baltimore and being "selected" to live in a better situation and make his steps towards freedom. But the point is that, based on this "deep conviction that slavery would not always be able to hold [him] within its foul embrace," Douglass resists and survives; "and in the darkest hours of [his] career in slavery, this living word of faith and spirit of hope departed not from [him], but remained like ministering angels to cheer [him] through the gloom" (DOUGLASS, 2009, p. 42). "This good spirit was from God," he says, "and to him I offer thanksgiving and praise" (p. 42). After that he is prepared to resist Mr. Covey oppression and even to fight with him, not using active violence in order to dominate him but to resist his attacks (GIBSON, 1985). In fact, after the narration of his fight with Mr. Covey, Douglass uses religious language again to convey the idea that "[it] was a glorious resurrection from the tomb of slavery to the heaven of freedom" (DOUGLASS, 2009, p. 78). Besides, Douglass is always asking god for justice in his narrative: "Will not a righteous God visit for these things?” (p. 58). And in another chapter: "O God, save me! God, deliver me! Let me be free! Is there any God? Why am I a slave?" then he finishes: "There is a better day coming" (p. 72). Douglass find in God the strength to resist oppression and the inspiration for his dreams of liberty. He uses culture in order to organize himself and resist the influence of society. This God Douglass addresses to is not Protestant, Catholic, Jewish, Muslim. He does not belong to a religious institution or to a specific country. Therefore, this kind of God is untamed.

Olaudah Equiano also finds in religion strength to resist and recreate culture. Just like Douglass, he cries for God's help and justice, looking "to that Heaven which protects the weak from the strong" (EQUIANO, 2018, p. 29). In another situation, he is named by the Captain of the ship Gustavo Vassa, but Equiano "refused to be called so, and told him as [he] could that [he] would be called Jacob" (p. 39), a Biblical name. Jacob is the name of the father of Israel, the pilgrim who had no home and dwelled in tents. Like Douglass, Equiano seems to show the same sense of being a chosen man in the hand of Providence. Narrating the story of the old poor Creole who told him: "I must look up to God Mighty in the top for right", 
Equiano confesses his strategy of assimilating the same value of religion in order to survive, resist injustice, and persist, as he says:

\begin{abstract}
This artless tale moved me much, and I could not help feeling the just cause Moses had in redressing his brother against the Egyptian. I exhorted the man to look up still to the God on the top, since there was no redress below. Though I little thought then that I myself should more than once experience such imposition, and need the same exhortation (EQUIANO, 2018, p. 79).
\end{abstract}

Based on his faith, he can criticize slavery as a cruel institution,

\begin{abstract}
a traffic [that] cannot be good, which spreads like pestilence, and taints what it touches! which violates that first natural right of mankind, equality and independency, and gives one man a dominion over his fellows which god never intend! For it raises the owner to a state as far above man as it depresses the slave below it; and, with all the presumption of human pride, sets a distinction between them, immeasurable in extent, and endless in duration! (EQUIANO, 2018, p. 79)
\end{abstract}

This rereading of religion gave them a new sense of community. Douglass, for example, talks of his fellow students and brothers with a dedication and expression embedded in religious language. He says:

We loved each other, and to leave them at the close of the Sabbath was a severe cross indeed. When I think that these precious souls are today shut up in the prison-house of slavery, my feelings overcome me, and I am almost ready to ask, "Does a righteous God govern the universe? And for what does he hold the thunders in his right hand, if not to smite the oppressor, and deliver the spoiled out of the hand of the spoiler?" (DOUGLASS, 2009, p. 85)

And forward he says:

I never loved any or confided in any people more than my fellow-slaves, and especially those with whom I lived at Mr. Freeland's. I believe we would have died for each other. We never undertook to do any thing, of any importance, without a mutual consultation. We never moved separately. We were one... (p. 86).
These passages are full of sentiment and religious intonation, communion, respect, dignity, nostalgia, and fellowship. Equiano demonstrates the same solidarity for his comrades of slavery when they are in trouble with white men and his friend "look up to God on high," which moved Equiano's pity for him; he gave him on third of his stock (EQUIANO, 2018, p. 82).

Equiano and Douglass also assimilate economic values of the Western culture in order to survive and resist oppression. Both writers achieve economic improvement and succeed in dealing with merchandise, buying and selling. Equiano learned with a master called Robert King, a Quaker, "and the first merchant in the place" (EQUIANO, 2018, p. 69), elements of arithmetic, gauging, and the office of a clerk. He worked as a clerk and earned day by day an amount of money "considerably more than was allowed to other slaves" (p. 70). "I had the good fortune to please my master in every department in which he employed me," Equiano says suggesting some kind of providential election. And then he says clearly that the "kind Providence seemed to appear rather more favourable to [him]" (p. 80). Equiano then "endevoured to try [his] luck and commence merchant" (p. 81) and begin his economic progress with a "very small capital", trusting "the Lord to be with him" (p. 81-2). And when his capital "amounted in all to a dollar" he "blessed the Lord [for being] so rich" (p. 82). He started to play the economic game of the Western culture and was going to win. The economic improvement is always related by Equiano to God's Providence, and it really marks the reverse of his fortune, which "proved no small encouragement for [him] to trust the Lord in any situation" (p. 84). So, the economical and the religious discourses are both in agreement. Being "from early years a predestinarian," he looked up with prayers anxiously to God for [his] liberty and at the same time used every honest means, and did 
all that was possible on [his] part to obtain it. [...] resisting oppression as well as I was able” (p. 86), according to the Calvinist doctrine. Therefore, he connects the assimilation of economic values and practices of that society with a conscious resistance to oppression and in a long pilgrimage toward freedom.

Douglass also understood that the path for liberty goes through the economic progress, and "[a]fter learning how to calk, [he] sought [his] own employment, made [his] own contracts, and collected the money which [he] earned" (DOUGLASS, 2009, p. 98). Afterward, he was allowed to "make all contracts with those form whom [he] worked, and find [his] own employment" (p. 103). "It was a step towards freedom to be allowed to bear the responsibilities of a freeman, and I was determined to hold on upon it," says Douglass (p. 103). Therefore, he overtly "bent [himself] to the work of making money" (p. 103) and succeeded.

Equiano and Douglass also used economic arguments against slavery, showing how it becomes an economic failure and gives no profit. Equiano calls slavery "a mistaken avarice" and points out England as an instance of "a freedom which diffuses health and prosperity" (EQUIANO, 2018, p. 79). On the other hand, by respecting human rights and "treating your slaves as men, every cause of fear would be banished. They would be faithful, honest, intelligent and vigorous; and peace, prosperity, and happiness, would attend you" (p. 79). Curiously, Derrida in his article against apartheid also comments that segregation gives no profit, "segregation hurts the market economy and training of labor" (DERRIDA, p. 1985, p. 295). And he continues by saying that the "apartheid is notoriously inefficient from the point of view of economic rationality" (p. 296). In spite of their different context, the apartheid regime and the $19^{\text {th }}$ have a common history of oppression, governmental tolerance, capitalist exploitation, as well as social and political segregation of black people.

Together with religion and economy, language is one of the most important elements of Douglass and Equiano acculturation and counteraction. By the assimilation of English and the use of it as their language they could succeed in organizing and recreating reality. Argyros calls attention to the importance of language as "a means of individual, cultural, and political empowerment" (ARGYROS, 1992, p. 661). They use the official English, the standard language, and through that language they can survive socially and communicate with a larger number of people (APPIAH, 1988). Gibson makes a comparison of Douglass's physical resistance to Mr. Covey aggressions and his verbal resistance, getting to the conclusion that "[b]ecause he has battled Covey successfully, he may speak, for he has earned the right to exercise the functions of higher consciousness" (GIBSON, 1985, p. 569). Douglass uses language in order to resist. There is a battle, a battle of discourses, a battle for power, and Douglass uses the official language, the language of culture, in order to present a counter-discourse.

Language is important not only for the sake of personal identity but of cultural identity of a people; as Gates Jr. comments, "[i]t has been the traditional role of the black poet [...] to be the point of consciousness, or superconsciousness, of his people. It is he who bridges the gap in tradition, he who modifies tradition when experience demands it, he who translates experience into meaning, meaning into belief" (GATE JR., 1983, p. 98). Taking this affirmation into consideration, we can see how Douglass's and Equiano's use of language is so important. Their narratives are instrument of resistance, of a recreation of the world "in the image of a people" (GATES JR., 1983, p. 98), between two movements of conservation and recreation. Their narratives created them while they created their narratives (ARGYROS, 1992, p. 669). 
Douglass's personal experience of learning to read and write was in itself an act of resistance. Douglass understood that the domination of written and spoken language was his "pathway from slavery to freedom" (DOUGLASS, 2009, p. 41). As he assimilated language through texts of Western culture and tradition - newspapers, his Mistress' books, The Columbian Orator (a book of rhetoric), and Western literature. With Sheridan he gained "tongue to interesting thoughts of [his] own soul" (p. 50), and with Sheridan he also learned the basic notions of "human rights". "Douglass invokes Hamlet (and Genesis) when he questions the value of knowledge, of rationality, and of life itself. He is fully aware of the connection between Hamlet and Genesis" (GIBSON, 1985, p. 560). He also learned language from abolitionist journals and magazines, using a lot his ability of public speaking, oratory, in order to support the abolitionist campaign. His book The Narrative of the Life of Frederick Douglass, an American Slave "became a best-seller on two continents and was translated into both French and German" (TRUDIER; THADIOUS; WHITAKER; DARROW, 1986, p. 85). He wrote pamphlets, gave lectures, edited magazines, wrote letters and used his tongue in order to resist oppression and spread out anti-slavery discourse, until he become personal friend of the President of the United States of America, Mr. Abraham Lincoln. While he was speaking "[his] whole soul was fired" (p. 84). "In form [his] style [was] very much influenced by contemporary oratorical practice" (GIBSON, 1985, p. 564).

Douglass finally gives an example of resistance against the institutional justice system when he forges some documents for the slaves who planned to flee from slavery. "I wrote," he says "several protections, one for each of us. As well as I can remember, they were in the following words, to wit: 'This is to certify that I, the undersigned, have given the bearer, my servant, full liberty to go to Baltimore, and spend the Easter holidays. Written with mine own hand, \&c., 1835"' (DOUGLASS, 2009 , p. 89). But this plan did not work, they were discovered. In spite of that, this extract gives an idea of how aware Douglass was of the necessity of using the elements of the American culture in order to resist, counteract, and even undermine this culture.

Frederick Douglass and Olaudah Equiano, throughout their narratives, exemplify how it is possible to construct a critical thinking about their own culture, and how it is possible to criticize an oppressive society and its institutions. They also exemplify how consciousness moves dialectically, assimilating and resisting cultural values, conserving some elements in order to recreate them. They show how it is possible to operate language to create a counter-discourse.

They also make us think about our position toward culture, questioning our responses if they are assimilative or critical. The questioning of cultural values and institutions is fundamental to our identity construction nowadays. As Said has suggested, "critical consciousness" is necessary to criticize power and question power relations (SAID, 1983, p. 619). And this criticism must be "always situated," "skeptical, secular, reflectively open to its own failings" (p. 619), in order to be always conscious and free of institutional character.

They finally present us a good example of how important narrative can be in the human life as an instrument of self-construction and social, political, religious independence. Narratives are a way of organizing reality and existence, giving name to the past and a perspective, a "theleios" (aim) to the future. In different terms, but similarly in some points, we are experiencing some cultural, historical, and social crisis in our contemporary times, when the possibility of a general narrative is being questioned and skepticism is the prevailing 
tone. At the same time, open racism, religious and political conservatism, and fanaticism are rampant and challenging democracy and social justice. Narratives were important in Douglass' and Equiano's times and are important nowadays as a way of organizing reality and recreating cultural identity.

\section{References}

APPIAH, Kwame Anthony. Out of Africa: Topologies of Nativism. The Yale Journal of Criticism, v. 2, n. 1, p. 153-178, 1988.

ARGYROS, Alex. Narrative and Chaos. New Literary History, n. 23, p. 659-673, 1992.

DAVIS, Charles T.; GATES, Henry Louis, Jr. (ed.). The Slaves' Narrative. New York: Oxford University Press, 1991.

DERRIDA, Jacques. Racism's last word. Transl. Peggy Kamuf Critical Inquiry, v. 12, n. 1, p. 290 299, Autumn 1985.

DOUGLASS, Frederick. Narrative of the Life of Frederick Douglass: an American Slave. Cambridge: Belknap, 2009.

EQUIANO, Olaudah. The Interesting Narrative of the Life of Olaudah Equiano, or Gustavus Vassa, the African, written by Himself. Oxford: Dodo Press, 2018.

GATES JR., Henry Louis. The Blackness of Blackness: a critique of the sign and the signifying monkey. Critical Inquiry, v. 9, n. 4, p. 685-723, June 1983.

GENOVESE, Eugene. A Terra Prometida: o Mundo que os Escravos Criaram. Trad. Maria Inês Rolim e Donaldson M. Garschagen. Rio de Janeiro: Paz e Terra, 1988.

GIBSON, Donald B. Reconciling public and private in Frederick Douglass' narrative. American Literature, v. 57, n. 4, p. 549-569,
December 1985.

LEVINE, Robert S. The slave narrative and the revolutionary tradition of American autobiography. In: FISCH, Andrey. The African American Slave Narrative. Cambridge: Cambridge Univ. Press, 2007. p. 99-114.

LOVEJOY, Paul E. "Freedom Narratives" of Transatlantic Slavery. Journal Slavery Abolition, v. 32, p. 91-107, 2011.

ROSENBLATT, Roger. Black Fiction. Cambridge, Massachusetts: Harvard University Press, 1974.

SAID, Edward. Secular Criticism. In:

The Text, the World, the Critic. Cambridge, Massachusetts: Harvard University Press, 1983. p. 1-30.

SANTOS, José Paiva dos. Autobiografia, apropriações e subversões: a literatura negra abolicionista nos Estados Unidos oitocentistas. 2011. Revista Vertentes, v. 19, n. 1, jan./jun. 2011.

SEKORA, John. Black Message/White Envelope: genre, authenticity, and authority in the antebellum slave narrative. Callaloo, n. 32, p. 482-515, Summer 1987.

TRUDIER, Harris; THADIOUS, Davis; WHITAKER, Russel; DARROW, Kathy. Dictionary of Literary Biography. Vol. 50. Farmington Hills, Michigan: Gale, 1986.

Submissão: setembro de 2020 . Aceite: outubro de 2020. 